THE PROTECTIVE ROLE Of POMEgranate(PUNICA GRANATUM) JUICE ON CHANGES INDUCED BY CARBENDAZIM IN SPERM CHARACTERISTICS IN RATS

\author{
By \\ Heba Ezz El-Din Youssef \\ Nutrition and Food Sciences Department, \\ Faculty of Home Economics \\ Minufiya University, Shibin El-Kom, Egypt
}

Research Gournal Specific Fducation

Faculty of Specific Fducation

Shansoura đniversity

ISSUE NO. 43, JULY. 2016

مجلة بعوث التربية النوعية - جامعة المنصورة

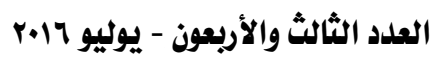


- The protective role of pomegranate(Punica granatum) juice on changes induced by carbendazim 


\title{
THE PROTECTIVE ROLE Of POMEGRANATE(PUNICA GRANATUM) JUICE ON CHANGES INDUGED BY CARBENDAZIM IN SPERM CHARACTERISTICS IN RATS
}

\author{
Heba Ezz El-Din Youssef
}

\section{Abstract}

Pomegranate fruit is used widely in the natural folk medicine in many cultures as a result of its anti-oxidant activity. The present study was aimed to evaluate the protective effects of pomegranate juice on carbendaziminduced oxidative stress and testes damage in rats. Rats were randomly divided into two main groups, the first group, negative control group (7 rats). The second group ,carbendazim groups (28) were treated with carbendazim $(150 \mathrm{mg} / \mathrm{kg}$ body weight) daily for 60 consecutive days. Carbendazim (CBZ) groups were divided into four equal subgroups as follow: subgroup1, positive control group, subgroups 2,3 and 4 received a daily oral dose 5,10 and $15 \mu \mathrm{L} / \mathrm{g}$ of body weight for 60 days of pomegranate juice. Prolonged administration of carbendazim produced increased significant malonaldehyde and decrease in the activities of glutathione transferase and catalase. Also carbendazim resulted in significant decrease in testosterone level, alteration in sperm count, motility, live sperm percent and also produced sperm abnormalities. Histopathological examination revealed degeneration and necrosis of spermatogoneal cells in rat testes treated with carbendazim only. The coadministration of pomegranate juice $(10 \mu \mathrm{L} / \mathrm{g}$ of B.W) with carbendazim alleviated the previous changes, whereas feeding rats with $15 \mu \mathrm{L} / \mathrm{g}$ of B.W of pomegranate juice reversed such changes to near the normal levels. On the other side carbendazim $+5 \mu \mathrm{L} / \mathrm{g}$ B.W of pomegranate juice group have less impact on reducing these changes. From the findings of present study it can be concluded that pomegranate juice supplementation reduced carbendazim-induced testicular toxicity and improved testicular function. Thus, it could have a role in improving fertility of rats.

* Nutrition and Food Sciences Department, Faculty of Home Economics, Minufiya University, Shibin El-Kom, Egypt 
- The protective role of pomegranate(Punica granatum) juice on changes induced by carbendazim

Keywords: Pomegranate, carbendazim, oxidative stress, sperm abnormalities.

\section{Introduction}

Male sexual dysfunction composed of several problems associated with sperm concentration, motility and hormonal imbalance e.g., low testosterone level, which are caused by alcoholism, drug abuse, aging and cigarette smoking, antidepressant drugs and exposure of toxic chemicals (Khan, 2012 and Othman et al.,2014). Furthermore, testicular oxidative stress plays a role in a number of conditions known to be detrimental to male fertility (Turner and Lysiak, 2008) and exposure to pesticide is one of the factors known to produce testicular oxidative stress leading to an increase in damaged apoptotic germ cells (Samanta and Chainy, 1997). Pesticides are being used as an integral part of modern agriculture practices. However, use of these pesticides is not highly regulated in developing countries (Ranjan et al., 2014). Carbendazim is extensively used on controlling various fungal pathogens and also used as a preservative in paint, textile, papermaking, leather industry and warehousing practices, as well as a preservative of fruits (Selmanoglu et al., 2001). It causes deleterious effects on various aspects of male reproduction in hamsters, mice, rats and humans. The effects include the decreased total sperm count, motility, increased incidence of sperm abnormalities (Akbarsha et al., 2001).

Pomegranate (Punica granatum) has been used in the folk medicine of many cultures especially in the Middle East (Gurib-Fakim, 2006). Fresh juice is rich in vitamin $\mathrm{C}$, and polyphenolic compounds such as anthocyanins, punicalagin, ellagic and gallic acid (Seeram et al., 2005) which can directly or indirectly reduce oxidative damage by preventing the excessive generation of free radicals (Al-Olayan et al., 2014). Pomegranate juice consumption increases significantly sperm quality, spermatogenic cell density, antioxidant activity and testosterone level in male rats (Turk et al., 2008). Therefore, this study aims to investigate the protective role of 
pomegranate juice on changes induced by carbendazim in sperm characteristics in rats.

\section{Material and Methods:}

\section{Materials}

Carbendazim (purity > 98.0\%) was provided by Weihai Pesticide Factory (Shandong, China). Kits were purchased from (Alkan Medical Company, St. El Doky, Cairo, Egypt). All other chemicals and reagents were obtained from El-Gomhoreya Company, Cairo, Egypt.

Pomegranate fruit (Punica granatum) was purchased from Shiben El-Kom, Minufiya, Egypt.

\section{Preparation of pomegranate juice:}

The fresh pomegranate was washed with tab water and squeezed without adding water in a Braun blender (Type 4979 made in Hungary) at a maximum speed for 15 minute. The juice was filtrated through cheesecloth. The pure filtrated juice was stored at $-20{ }^{\circ} \mathrm{C}$ until used.

\section{Animals:}

Thirty fife adult male Sprague-Dawley rats weighing $(170 \pm 5 \mathrm{~g})$, at the beginning of the experiment, were obtained from Medical Insects Research Institute, Doki, Cairo, Egypt. Rats were housed individually in wire cages under the normal laboratory conditions. Rats were fed on standard diet for one week as an adaptation period. Diet was introduced to rats in special food cups to avoid scattering of food. Also, water was provided to rats by glass tubes projecting through the wire cages from an inverted bottle supported to one side of the cage. Food and fresh water were provided checked daily. Standard diet was prepared from fine ingredients according to AIN-93 guidelines (Reeves et al., 1993). All animals were received care in compliance with the Egyptian rules for animal protection.

\section{Experimental groups:}

Rats were randomly divided into two main groups, the first group, negative control group $(\mathrm{n}=7)$ fed standard diet. The second group ,Carbendazim groups $(n=28)$ were exposed to carbendazim dissolved in 
corn oil by oral gavage at dosage of $150 \mathrm{mg} / \mathrm{kg}$ daily for 60 consecutive days to cover the spermatogenic cycle according to Hershberger, et al. (1969). The negative control rats were administered to the equal volume redistilled water and corn oil. Carbendazim groups were divided into four subgroups ( 7 rats each) as follow: subgroup 1 served as positive control group, subgroup 2,3 and 4 received basal diet and given fresh pomegranate juice orally by gavages 5,10 and $15 \mu \mathrm{l} / \mathrm{g}$ of body weight respectively once a day for 60 days, as described by Park et al., (2003). After 60 days, the animals were euthanized by decapitation. The testes, seminal vessel and prostate were promptly excised, weighed. The right testis from each animal was removed and was stored at $-80 \circ \mathrm{C}$ for further analysis. testicular homogenate was prepared in ice cold $0.1 \mathrm{M}$ potassium phosphate buffer $(\mathrm{pH}$ 7.4). The homogenate was centrifuged at $4000 \mathrm{rpm}$ for $15 \mathrm{~min}$ to harvest supernatant. Supernatant was used for estimation the various biochemical determinations. Serum was removed by centrifugation of the blood (5 minutes at $3000 \mathrm{rpm})$. Serum was transferred into clean cuvette tube and stored at $-20^{\circ} \mathrm{C}$ until analysis.

\section{Methods}

\section{Chemical composition and determine of bioactive compounds:}

Protein, fat, moisture, ash and ascorbic acid contents were determined in pomegranate juice according to AOAC, (2012). The carbohydrate was calculated by difference. The determination of total phenols was carried out by using Folin-Ciocalteuas described by Chun et al., (2003). Total phenolic compounds were expressed as mg gallic acid equivalents / $100 \mathrm{~g}$ dry weight sample. Total flavonoids were determined using a method described by Franke et al., (2004).Total flavonoids were expressed as mg catechin / $100 \mathrm{~g}$ dry weight sample. Anthocyanin was determined as described by Lako et al., (2007).

Enzymatic antioxidant status, oxidative stress and testosterone hormone

Homogenate of testes were used in determination of Catalase, glutathione transferase (GTH) and malonaldehyde (MDA) according to the 
methods described by Aebi, (1983), Habig et al., (1973) and Ohkawa et al., (1979) respectively. Testosterone hormone was assayed in serum using kit according to manufacturer's protocol.

Sperm count, motility, sperm viability and sperm abnormalities

In brief, seminal fluid was diluted with $0.2 \%$ of eosin solution and was observed under the microscope for sperm count and motility described by Ngoula, et al., (2007). Sperm viability and sperm abnormalities were carried out by mixing the drop of seminal fluid with the drop of eosin and nigrosin stain and observed under the microscope according to Bearden and Fuquay, (1997).

\section{Histopathology examination}

The left testes were collected and immediately fixed with $10 \%$ buffered formalin, dehydrated in ascending concentration of ethanol (70, 80 and $90 \%)$, cleared in zylene and embedded in paraffin. Sections $(4-5 \mu \mathrm{m})$ were prepared and then stained with hematoxylin and eosin dye according to Bancroft and Stevens, (1996).

Statistical analysis:

Results were expressed as the mean \pm SD. Data for multiple variable comparisons were analyzed by one-way analysis of variance (ANOVA). For the comparison of significance between groups, Duncan's test was used as a post hoc test according to the statistical package program (SPSS version 17.0).

\section{Results and discussion}

Vitamin C, total flavonoids, anthocyanins and total phenols contents of fresh pomegranate juice were presented in Fig (1). Fresh pomegranate juice had 85, 136.5, 184.83 and $1328.57 \mathrm{mg} / \mathrm{L}$ for vitamin $\mathrm{C}$, total flavonoids, anthocyanins and total phenols respectively. These results are in the same trend of Hassan et al., (2012) who showed that vitamin $\mathrm{C}$ and anthocyanins content ranged between 27.7-94.8 and 45-1480 mg/L respectively. Also total phenolic compounds of pomegranate juice were in the range values (1245 to $2076 \mathrm{mg} / \mathrm{L}$ ) reported by özgen et al., (2008). On 
the other side total flavonoids of pomegranate juice were much higher than the value (5.25 mg rutin/100 ml) reported by Elfalleh et al., (2012).

Data in Table (2) showed the effect of pomegranate juice on antioxidant enzymes and oxidative stress parameter of testicular tissues in rats. The repeated administration of carbendazim (CBZ) resulted in increase in lipid peroxidation (MDA) and decrease glutathione transferase (GST) and catalase activities in testicular tissue in CBZ control compared with negative control. Increase of lipid peroxidation could be due to carbendazim-induced formation of free radicals. These findings are supported by Rajeswary et al. (2007) and Metwally et al. (2011) who reported that exposure rats to CBZ resulted in a significant increase in testicular tissue level of MDA whereas glutathione peroxidase and catalase enzymes activities were significantly decreased. Moreover carbendazim induces testicular oxidative stress leading to generation of free radicals and alterations in the antioxidants or oxygen free radical scavenging enzymes such as catalase and glutathione transferase (Rajeswary et al., 2007). After administration of rats with $\mathrm{CBZ}+10$ and $15 \mu \mathrm{L} / \mathrm{g} \mathrm{BW}$ of pomegranate juice (PJ) for 60 days, the levels of GST and catalase activities were increased and MDA decreased in testicular tissue as compared to CBZ control rats. However the levels of GST and catalase in the $\mathrm{CBZ}+5 \mu \mathrm{L} / \mathrm{g}$ BW of PJ group did not differ from CBZ control group. Our results show that the protective effect of pomegranate juice may be due to both an increase in the activity of the antioxidant-defense system and an inhibition of lipid peroxidation production. This results confirmed the results of Afaq et al., (2005) who reported that pomegranate is an important source of anthocyanins and phenolic compounds which are known for their properties in scavenging free radicals and inhibiting lipid oxidation in vitro (Li et al., 2006). In the same table the results indicated that in CBZ + $15 \mu \mathrm{L} / \mathrm{g} \mathrm{BW}$ of PJ, GST, catalase activities and MDA were restored to negative control values. These results are agreement with Turk rt al., (2008) who demonstrated that increases observed in sperm CAT and GSH activities of high dose $\mathrm{PJ}(1 \mathrm{ml} /$ day $)$ group when compared to the control, the low $(0.25 \mathrm{ml} /$ day $)$ and middle $(0.5 \mathrm{ml} /$ day $)$ doses of PJ groups. 
The effect of pomegranate juice on testosterone, sperm count, sperm motility, live sperm and sperm abnormality of rats are shown in Table (3). Plasma testosterone level was significant decrease $(p \leq 0.05)$ in CBZ groups as compared with negative control group. This decrease may be due to the increasing of lipid peroxidation(LPO), decrease GST and catalase activities as a result of expose to CBZ. These results confirmed the results of Santos et al., 2004) who reported that secretion of testosterone is probably impaired due to excessive oxidative stress and the degeneration of Leydig cells. Likewise Lu et al., (2006) showed that if antioxidant system cannot neutralized produce reactive oxygen species, the mitochondrial membrane will be stripped and led to inhibition of testosterone production. Co administration of carbendazium with pomegranate juice led to improve the level of testosterone as well as the testosterone level showed an increasing tendency with increasing dose PJ. This increase of testosterone level may be due to the ability of pomegranate to reduce oxidative stress caused by CBZ administration. The result of this study came in accordance with that reported by Al- Olayan et al., (2014) who observed that treatment of rats with pomegranate juice ameliorated the toxic effects of CCl4 and the levels of testosterone was increased. Also the results indicated that, after treatment of rats with CBZ for 60 days, the sperm count, sperm motility, live perm were decreased significantly $(\mathrm{P} \leq 0.05)$ in carbendazim groups as compared to negative control group while, sperm abnormality had opposite trend. Our results corroborate the findings of Ranjan et al., (2014) who observed that significant decline in total sperm count, live sperm percentage and increased sperm abnormalities after 45 and 90 days of exposed rats to CBZ as compared to control. Metwally et al., (2011)found that significantly reduced in total sperm count and motility in rats after exposure to CBZ. Data in the same table showed no significant differences $(P>0.05)$ in sperm motility, live sperm and sperm abnormality were observed in CBZ control and $\mathrm{CBZ}+5 \mu \mathrm{L} / \mathrm{g} \mathrm{BW}$ of PJ groups. On the other side supplementation rats with 10 and $15 \mu \mathrm{L} / \mathrm{g}$ BW of PJ had positive effect on sperm count, sperm motility, live perm and sperm abnormality. This positive effect may be related to phenolic compounds, vitamine $\mathrm{C}$ and anthocyanins present in 
pomegranate juice. The highest improvement in percent of sperm count, sperm motility, live sperm and sperm abnormality were found in CBZ group supplemented with $15 \mu \mathrm{L} / \mathrm{g}$ BW of PJ. These results indicated that there was partial restoration in testosterone, sperm count, live sperm percent and sperm abnormalities in the CBZ supplemented with 10 and $15 \mu \mathrm{L} / \mathrm{g} \mathrm{BW}$ of PJ group as compared to $\mathrm{CBZ}$ control and $\mathrm{CBZ}+5 \mu \mathrm{L} / \mathrm{g} \mathrm{BW}$ of PJ groups. These results are agreement with Mansour et al., (2013) who noted that PJ consumption significantly increased epididymis sperm concentration and sperm motility parameters and decreased abnormal sperm production. Also Turk et al., (2008) demonstrated that consumption high dose of PJ for seven weeks caused increased spermatogenic cell density, epididymal sperm concentration, sperm motility and decreased abnormal sperm rate related with decreased lipid peroxidation in male rats as compared with control group. Benefits of pomegranate juice on sperm quality and male fertility of rats were reported by Sonmez et al., (2005).

Table (4) showed the effect of pomegranate juice on testes, seminal vessel and prostate weights of rats. There were significant decrease $(p \leq .05)$ in testes weight among CBZ control, $\mathrm{CBZ}+5 \mu \mathrm{L} / \mathrm{g} \mathrm{BW}$ of PJ groups and negative control and $\mathrm{CBZ}+10$ and $15 \mu \mathrm{L} / \mathrm{g} \mathrm{BW}$ of PJ groups. This observation is in consonance with Q Guo et al., (2009) who found that the testis weights was decreased after exposure to carbendazim at 100 and 200 $\mathrm{mg} / \mathrm{kg}$ for 80 days, indicating that carbendazim had adverse effect on the development of rats testes. Moreover in general toxicity studies, it is well known that the changes in organ weights are sensitive indicators of the detection of potentially toxic chemicals (Bailey et al., 2004 and Kim et al., 2004). The values of testes, seminal vessel and prostate weights in CBZ control group were significantly $(\mathrm{P} \leq 0.05)$ lower than negative control group and CBZ groups supplemented with PJ with the exception of testes weight for CBZ group given $5 \mu \mathrm{L} / \mathrm{g}$ BW of $\mathrm{PJ}$ which was similar $(\mathrm{P}>0.05)$ to $\mathrm{CBZ}$ group. Supplementation rats with 10 and $15 \mu \mathrm{L} / \mathrm{g} B W$ of pomegranate juice did not significant differ $(\mathrm{P}>0.05)$ in their effect on seminal vessel and prostate weights. Also no significant difference was found in testis and prostate weights between $\mathrm{CBZ}+15 \mu \mathrm{L} / \mathrm{g} \mathrm{BW}$ of PJ and negative control 
groups. The reduction of prostate weight can be explained by the loss of secretion from the prostate which caused by a drop in testosterone production (Salem et al.,2012).

Fig. (2) showed the testis histopathology of negative, positive and carbendazim rats administrated with different concentration of pomegranate juice. The control rats showed that no histopathological changes, normal spermatogenesis, well preserved Sertoli cells and well delineated tubular basement membrane were observed. However, CBZ control and CBZ + 5 $\mu \mathrm{L} / \mathrm{g} \mathrm{BW}$ of PJ groups showed degeneration and necrosis of spermatogoneal cells lining seminiferous tubules and interstitial oedema. Supplementation rats with 10 and $15 \mu \mathrm{L} / \mathrm{g} \mathrm{BW}$ of pomegranate juice caused reduce the toxic effects of carbendazim and improve the testes tissue. These results agree with those reported by Gongchang et al., (2009) and Ibtihag et al., (2011).

\section{Conclusion}

The results obtained proved the pomegranate juice potentials to counteract all carbendazium - induced changes thus allowing recovery of the rats from oxidative stress and hence contributing in improving fertility. Farm workers may have highest persons for exposure to potential hazards of pesticides. Therefore, it is recommended to supplement pomegranate juice for these individuals for protecting them from side effects of pesticides on fertility.

\section{Acknowledgments}

I thank professor Abdel-Hamid Abdel-Mageed Nahas. Researcher in Mammalian Toxicology Department, Central Agricultural Pesticide Laboratory, for his cooperation and aid in determination of sperm count, motility, sperm viability and sperm abnormalities. 


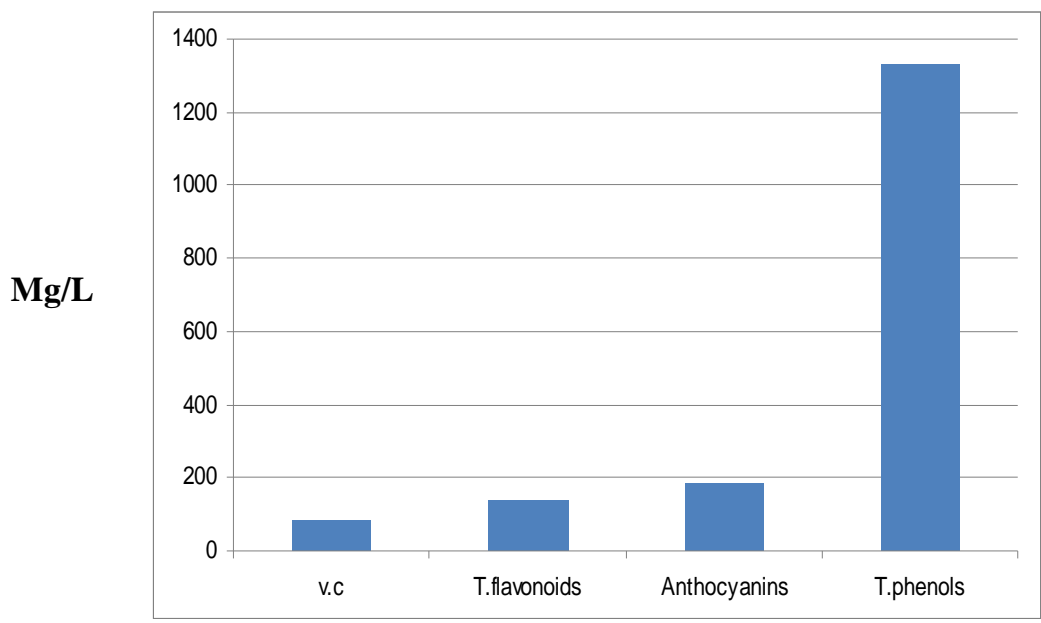

Fig (1) : Vitamin C, T. flavonoids, anthocyanins and T. phenols contents of fresh pomegranate juice.

Table (2): Effect of pomegranate juice on antioxidant enzymes and oxidative stress parameters in in testicular tissues rats.

\begin{tabular}{|c|c|c|c|c|c|}
\hline \multirow[b]{2}{*}{ Parameters } & \multirow{2}{*}{$\begin{array}{c}\text { Negative } \\
\text { control } \\
\text { group }\end{array}$} & \multicolumn{4}{|c|}{ Carbendazim groups } \\
\hline & & CBZ control & $\begin{array}{c}\mathrm{CBZ} \pm \mathrm{PJ}(5 \\
\mu \mathrm{L} / \mathrm{g} \text { of } \mathrm{B} . \mathrm{W})\end{array}$ & $\begin{array}{l}\mathrm{CBZ} \pm \mathrm{PJ}(10 \\
\mu \mathrm{L} / \mathrm{g} \text { of } \mathrm{B} . \mathrm{W})\end{array}$ & $\begin{array}{l}\mathrm{CBZ} \pm \mathrm{PJ}(15 \\
\mu \mathrm{L} / \mathrm{g} \text { of } \mathrm{B} . \mathrm{W})\end{array}$ \\
\hline MDA (nmol/g tissue) & $10.03^{\mathrm{d}} \pm 0.54$ & $17.10^{\mathrm{a}} \pm 1.02$ & $14.63^{\mathrm{b}} \pm 1.3$ & $12.57^{\mathrm{c}} \pm 1.03$ & $10.23^{\mathrm{d}} \pm 0.57$ \\
\hline GST( $\mu \mathrm{mol} / \mathrm{g}$ tissue $)$ & $0.67^{\mathrm{a}} \pm 0.02$ & $0.40^{\mathrm{c}} \pm 0.01$ & $0.42^{c} \pm 0.02$ & $0.49^{b} \pm 0.01$ & $0.65^{\mathrm{a}} \pm 0.02$ \\
\hline CAT (U/g tissue) & $5.63^{\mathrm{a}} \pm 0.13$ & $2.89^{\mathrm{c}} \pm 0.11$ & $2.99^{c} \pm 0.10$ & $4.30^{\mathrm{b}} \pm 0.01$ & $5.60^{\mathrm{a}} \pm 0.21$ \\
\hline
\end{tabular}

Data are expressed as mean \pm SD. Means in the same row with different letters are significantly different $(\mathrm{p} \leq 0.05)$. $\mathrm{PJ}$ : pomegranate juice, CBZ: carbendazim, MDA: malonaldehyde ,GST: Glutathione transferase., CAT: catalase 
Table (3): Effect of pomegranate juice on serum testosterone, sperm count, sperm motility, live and abnormality of rats.

\begin{tabular}{|c|c|c|c|c|c|}
\hline \multirow[t]{2}{*}{ Parameters } & \multirow{2}{*}{$\begin{array}{l}\text { Negative } \\
\text { control }\end{array}$} & \multicolumn{4}{|c|}{ Carbendazim groups } \\
\hline & & CBZ control & $\begin{array}{c}\mathrm{CBZ} \pm \mathrm{PJ}(5 \\
\mu \mathrm{L} / \mathrm{g} \text { of } \mathrm{B.W})\end{array}$ & $\begin{array}{l}\mathrm{CBZ} \pm \mathrm{PJ}(10 \\
\mu \mathrm{L} / \mathrm{g} \text { of } \mathrm{B} . \mathrm{W})\end{array}$ & $\begin{array}{l}\mathrm{CBZ} \pm \mathrm{PJ}(15 \\
\mu \mathrm{L} / \mathrm{g} \text { of } \mathrm{B} . \mathrm{W})\end{array}$ \\
\hline T.T (ng/dl) & $5.04 \mathrm{a} \pm 0.08$ & $1.03 \mathrm{e} \pm 0.05$ & $1.71 \mathrm{~d} \pm 0.03$ & $2.40 \mathrm{c} \pm 0.09$ & $3.42 b \pm 0.07$ \\
\hline Sperm count $(\%)$ & $94.75 \mathrm{a} \pm 1.7$ & $40.50 \mathrm{e} \pm 2.4$ & $44.00 \mathrm{~d} \pm 0.82$ & $47.25 \mathrm{c} \pm 2.2$ & $61.50 \mathrm{~b} \pm 1.9$ \\
\hline Sperm motility $(\%)$ & $77.52 \mathrm{a} \pm 2.4$ & $37.75 \mathrm{~d} \pm 2.1$ & $39.82 \mathrm{~d} \pm 0.97$ & $43.63 c \pm 2.0$ & $47.37 b \pm 3.3$ \\
\hline Live (\%) & $87.50 \mathrm{a} \pm 1.7$ & $54.50 \mathrm{c} \pm 1.3$ & $55.25 c \pm 1.7$ & $84.00 \mathrm{~b} \pm 1.8$ & $86.00 \mathrm{a} \pm 0.82$ \\
\hline Abnormality (\%) & $10.88 c \pm 0.67$ & $46.00 \mathrm{a} \pm 4.5$ & $45.50 \mathrm{a} \pm 4.2$ & $15.75 b \pm 0.96$ & $13.50 b c \pm 1.3$ \\
\hline
\end{tabular}

Data are expressed as mean \pm SD. Means in the same row with different letters are significantly different $(\mathrm{p} \leq 0.05)$. PJ : pomegranate juice, CBZ: carbendazim, T.T: testosterone .

Table (4): Effect of fresh pomegranate juice on testes, seminal vessel, and prostate weights of rats.

\begin{tabular}{|c|c|c|c|c|c|}
\hline \multirow[b]{2}{*}{ Parameters } & \multirow{2}{*}{$\begin{array}{c}\text { Negative } \\
\text { control group }\end{array}$} & \multicolumn{4}{|c|}{ Carbendazim groups } \\
\hline & & CBZ control & $\begin{array}{c}\mathrm{CBZ} \pm \mathrm{PJ}(5 \\
\mu \mathrm{L} / \mathrm{g} \text { of } \mathrm{B} . \mathrm{W})\end{array}$ & $\begin{array}{l}\mathrm{CBZ} \pm \mathrm{PJ}(10 \\
\mu \mathrm{L} / \mathrm{g} \text { of } \mathrm{B} . \mathrm{W})\end{array}$ & $\begin{array}{l}\mathrm{CBZ} \pm \mathrm{PJ}(15 \\
\mu \mathrm{L} / \mathrm{g} \text { of } \mathrm{B} . \mathrm{W})\end{array}$ \\
\hline Testes weight (mg) & $2.25 \mathrm{a} \pm 0.06$ & $1.88 \mathrm{c} \pm 0.05$ & $1.79 \mathrm{c} \pm 0.05$ & $2.06 \mathrm{~b} \pm 0.06$ & $2.21 \mathrm{a} \pm 0.06$ \\
\hline Seminal vessel(mg) & $0.31 \mathrm{a} \pm 0.01$ & $0.22 \mathrm{~d} \pm 0.01$ & $0.25 \mathrm{c} \pm 0.02$ & $0.26 \mathrm{bc} \pm 0.01$ & $0.27 \mathrm{~b} \pm 0.01$ \\
\hline Prostate (mg) & $0.33 \mathrm{a} \pm 0.01$ & $0.23 \mathrm{c} \pm 0.01$ & $0.31 \mathrm{~b} \pm 0.004$ & $0.33 \mathrm{a} \pm 0.01$ & $0.34 \mathrm{a} \pm 0.01$ \\
\hline
\end{tabular}

Data are expressed as mean \pm SD. Means in the same row with different letters are significantly different $(\mathrm{p} \leq 0.05)$. $\mathrm{PJ}$ : pomegranate juice, CBZ: carbendazim 


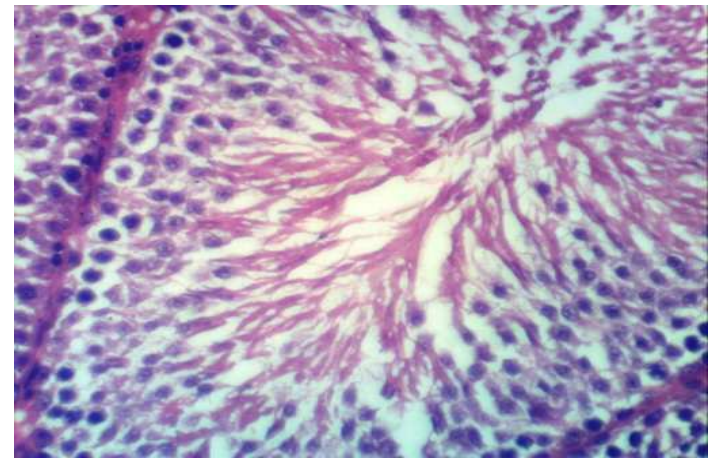

Negative control rats
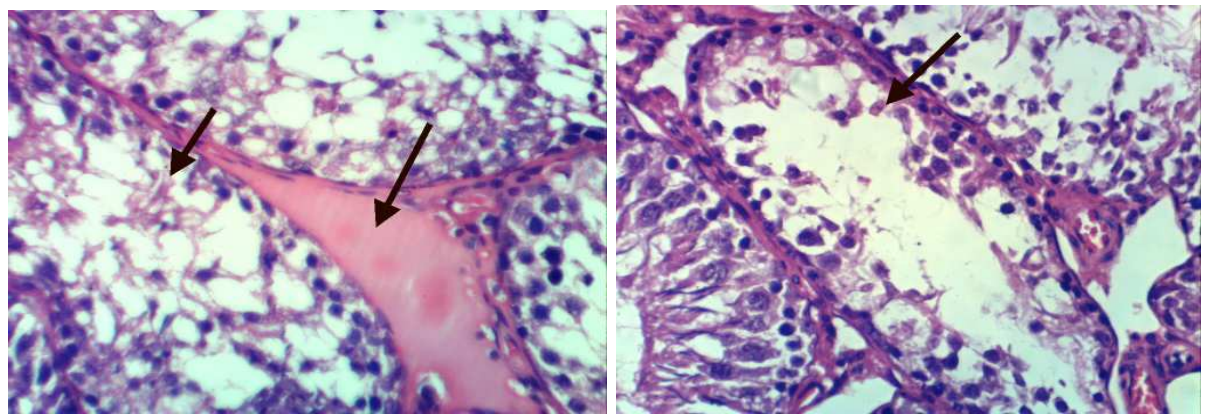

\section{CBZ control rats}

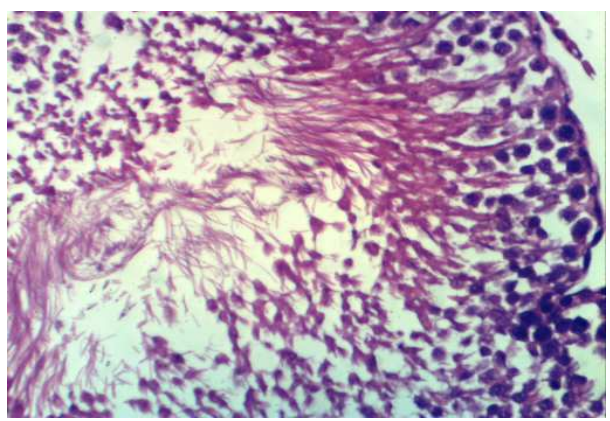

CBZ rats \pm PJ $(10 \mu \mathrm{L} / \mathrm{g}$ of B.W $)$
CBZ rats \pm PJ $(5 \mu \mathrm{L} / \mathrm{g}$ of $\mathrm{B} . \mathrm{W})$

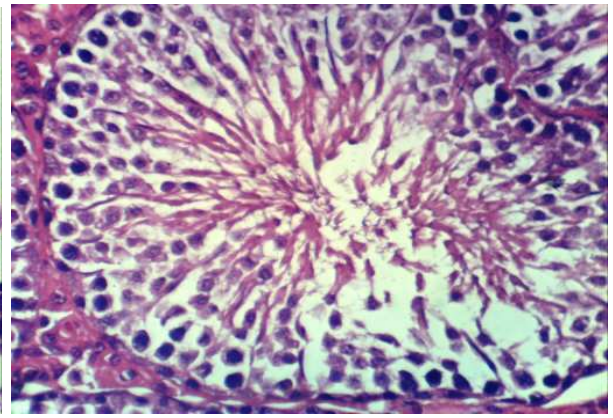

CBZ rats \pm PJ $(15 \mu \mathrm{L} / \mathrm{g}$ of B.W)

CBZ: carbendazim, $\mathrm{PJ}$ : pomegranate juice

Fig (2): Testis histopathology of negative, positive and carbendazim rats administrated with different concentration of pomegranate juice 


\section{References}

1. A.O.A.C. (2012).International Official Methods of Analysis. $19^{\text {th }}$ ed., Gaithersburg, MD: AOAC International.

2. Aebi, H.U. (1983). Catalase in methods in enzymatic analysis," in Methods in Enzymatic Analysis, U. H. Bergmeyer, Ed., 3: 276-286, Academic Press, New York, NY, USA.

3. Afaq, F.; Saleem, M.; Krueger, C.G.; Reed, J.D. and Mukhtar, H. Anthocyanin- and hydrolyzable tannin-rich pomegranate fruit extract modulates MAPK and NF-kB pathways and inhibits skin tumorigenesis in CD1 mice.Int J Cancer 2005;113:423-433.

4. Akbarsha, M.A.; Kadalmani, B.; Girija, R.; Faridha, A.; Shahul, k. and Hamid, K.( 2001). Spermatotoxic effect of carbendazim. Indian J Exp Biol;39:921-4.

5. Al-Olayan, E.M.; El-Khadragy, M.F.; Metwally, D.M. and Abdel Moneim, A.E. (2014). Protective effects of pomegranate (Punica granatum) juice on testes against carbon tetrachloride intoxication in rats. Complementary and Alternative Medicine,14:164-172.

6. Bailey, S.A.; Zidell, R.H. and Perry, R.W. (2004) Relationships between organ weight and body/brain weight in the rat: what is the best analytical endpoint? Toxicol Patho., 132: 448-466.

7. Bancroft, J.D. and Stevens, A. (1996): The haematoxylin and eosin. Theory and practice of histological techniques. 4th ed, Ch. Churchill Livingstone, London, New York \& Tokyo,6: 99-112.

8. Bearden, H.J., Fuquay, J.W. (1997). Semen collection. In: Applied Animal Reproduction, 4th ed. Prentice Hall, New Jersey, pp. 147- 157.

9. Elfalleh, W.; Hannachi, H.; Tlili, N.; Yahia, Y.; Nasri, N. and Ferchichi, A. (2012).Total phenolic contents and antioxidant activities of pomegranate peel, seed, leaf and flower. Journal of Medicinal Plants Research, 6:4724-4730.

10. Franke, A.A.; Custer, L.J.; Arakaki, C. and Murphy, S.P. (2004).Vitamin $\mathrm{C}$ and flavonoid levels of fruits and vegetables consumed in Hawaii. Journal of Food Composition and Analysis, 17(1): 1-35.

11. Gurib-Fakim, A. (2006). Medicinal plants: traditions of yesterday and drugs of tomorrow. Mol Aspects Med, 27:1e93. 
$=$ The protective role of pomegranate(Punica granatum) juice on changes induced by carbendazim

12. Habig, W.H.; Pabst, M.J. and Jakoby, W.B. (1973). Glutathione-Stransferase. The first enzymatic step in mercapturic acid formation. J Biol Chem., 249:7130-7139.

13. Hassan, N. A. .; El- Halwagi, A. A. and Sayed, H.A.(2012). Phytochemicals, Antioxidant and Chemical Properties of 32 Pomegranate Accessions Growing in Egypt. World Applied Sciences Journal 16 (8): 1065-1073.

14. Hershberger, L.G.; Hansen, D.H. and Hansen, L.D. (1969). Effect of antifertility agents on male mice and rats as determined by a serial mating technique. Proc Soc Exp Biol Med, 131: 669-670.

15. Ibtihag, F. ;El Ghazzawy, A. E.; Meleis, E. F. and Farghaly, A. S.(2011): Histological study of the possible protective effect of pomegranate juice on bisphenol-A induced changes of the caput epididymal epithelium and sperms of adult albino rats. Alexand. J. of Med. 47:125-137.

16. Khan, R.A.(2012). Protective effects of Launaea procumbenson rat testis damage by CCl4.Lipids Health Dis, 11:103.

17. Kim, J.C.; Shin, D.H, Kim, S.H.; Kim, J.K.; Park, S.C. and Son, W.C. (2004). Sub acute toxicity evaluation of a new camptothecin anticancer agent CKD-602 administered by intravenous injection to rats. Regul Toxicol Pharmacol, 40: 356-369.

18. Lako, J.; Trenerry, V.C.; Wahlqvist, M.; Wattanapenpaiboon, N.; Sotheeswaran, S. and Premier, R. (2007). Phytochemical flavonols, carotenoids and the antioxidant properties of a wide selection of Fijian fruit, vegetables and other readily available foods. Food Chemistry, 101: 1727-1741.

19. Li, Y.; Guo, C., Yang, J.; Wei, J.; Xu, J. and Cheng, S.(2006): Evaluation of antioxidant properties of pomegranate peel extract in comparison with pomegranate pulp extract. Fd. Chem., 96: 254-260.

20. Lu, L.; Chen, H.; Trush, M.A.; Show, M.D.; Anway, M.D.; Zirkin, B.R.(2006). Aging and the brown Norway rat Leydig cell antioxidant defense system. J. Androl, 27, 240-247.

21. Mansour SW, Sangi S, Harsha S, Khaleel MA, Ibrahim AR and Eldin TA. (2013). Sensibility of male rats fertility against olive oil, Nigella sativaoil and pomegranate extract. Asian Pac J Trop Biomed, 3: 563-568,. 
22. Metwally, S.A.; Hekma, A.A.; Hala, M. and Hamdy, A., (2011). The protective effect of linseed oil against carbendazim induced testicular toxicity in rats. Eur. J. Sci. Res., 49: 208-224.

23. Ngoula, F.; Watcho, P.; Dongmo, M.C.; Kenfack, A.; Kamtchouing, P. and Tchoumboué, J. (2007). Effects of pirimiphos-methyl (an organophosphate insecticide) on the fertility of adult male rats. Afr Health Sci., 7: 3-9.

24. Ohkawa, H.; Ohishi, N. and Yagi, K. (1979). Assay for lipid peroxides in animal tissues by thiobarbituric acid reaction. Anal. Biochem., 95(2):351-358.

25. Othman, M.S.; Nada, A.; Zaki, H.S. and Abdel Moneim, A.E. (2014). Effect of Physalis peruviana L. on cadmium-induced testicular toxicity in rats. Biol Trace Elem Res2014,:2014. doi:10.1007/s12011-014-9955-1.

26. özgen, M., Durgac, C., Serce, S. and Kaya, C. (2008). Chemical and antioxidant properties of pomegranate cultivars grown in Mediterranean region of Turkey. Food Chemistry, 111:703-706.

27. Park, Y.K.; Park, E.; Kim, J.S. and Kang, M.H. (2003). Daily grape juice consumption reduces oxidative DNA damage and plasma free radical levels in healthy Koreans. Mutat. Res.,529:77-86.

28. Q-Guo,G. Y.; Xie, L.; Liu, Y. and Wang, X. (2009). Effects of subchronic exposure to carbendazim on spermatogenesis and fertility in male rats. Toxicology and Industrial Health, 25:41-47.

29. Rajeswary, S.; Kumaran, B.; Ilangovan, R.; Yuvaraj, S.; Sridhar, M.; Venkataraman, P.; Srinivasan, N. and Aruldhas, M.M. (2007). Modulation of antioxidant defense system by the environmental fungicide carbendazim in Leydig cells of rats. Reprod. Toxicol, 24, 371-380.

30. Ranjan, B.; Daundkar, P.S. and Rampal, S. (2014). Ameliorative effect of selenium on carbendazim induced oral sub-chronic testicular toxicity in bucks. Small Ruminant Research, 119: 107-113.

31. Reeves, P. G.; Nielsen, F. H. and Fahey, G. C. (1993). AIN-93 purified diets for laboratory rodents: final report of the American Institute of Nutrition adhoc writing committee on the reformulation of the AIN- 76 A rodent diet. J. Nutr., 123: 1939-1951. 
- The protective role of pomegranate(Punica granatum) juice on changes induced by carbendazim

32. Salem, E. A.; Salem, N.A.; Maarouf, A.M.; Serefoglu, E.C. and Hellstrom, W. J. (2012). Selenium and lycopene attenuate cisplatin-induced testicular toxicity associated with oxidative stress in wistar rats. Urology, 79 (5):1184.

33. Samanta, L. and Chainy, G.B. (1997). Comparison of Hexachlorocyclohexane induced oxidative stress in the testis of immature and adult rats. Comp. Biochem. Physiol. C: Toxicol. 3, 319-327.

34. Santos AM, Ferraz MR, Teixeira CV, Sampaio FJ, Da Fonte RC:Effects of undernutrition on serum and testicular testosterone levels and sexual function in adult rats. Horm Metab Res2004,36(1):27-33.

35. Seeram NP, Adams LS, Henning SM, et al.(2005). In vitro antiproliferative, apoptotic and antioxidant activities of punicalagin, ellagic acid and a total pomegranate tannin extract are enhanced in combination with other polyphenols as found in pomegranate juice.J Nutr Biochem,16:360e7.

36. Selmanoglu G, Barlas N, Songur S, Kockaya EA. (2001). Carbendazim induced haematological, biochemical and histopathological changes to the liver and kidney of male rats. Hum Exp Toxicol;20:625-30.

37. Sonmez, M.; Turk, G. and Yuce, A.(2005):The effect of ascorbic acid supplementation on sperm quality, lipid peroxidation and testosterone levels of male Wistar rats. Theriogenology .63: 2063-2072.

38.Sonmez, M.; Turk, G. and Yuce, A. (2005). The effect of ascorbic acid supplementation on sperm quality, lipid peroxidation and testosterone levels of male Wistar rats. Theriogenology, 63(15):2063-2072.

39. Turk, G.; Sömmez, M. and Aydin M. (2008). Effects of pomegranate juice consumption on sperm quality, spermatogenic cell density, antioxidant activity and testosterone level in male rats. Clin Nutr., 27:289-296.

40. Turner, T.T. and Lysiak, J.J. (2008). Oxidative stress: a common factor in testicular dysfunction. J. Androl. 5, 488-498.

41. Yu, G.; Liu, Y.; Xie, L. and Wang, X.(2009). Involvement of Sertoli cells in spermatogenic failure induced by carbendazim. Environmental Toxicology and Pharmacology, 27: 287-292. 


\title{
الدور الوقائي لعصير الرهان على التغيرات التي يصدثها الكاربندزيم
}

\section{في خصائص الحيوانات المنوية في الفئران}

$*$ هبه عز الدينيوسف

\author{
الملاخص العربي
}

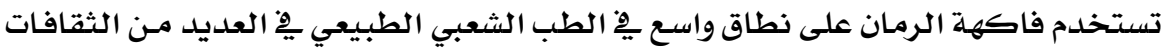

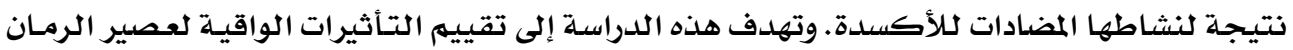

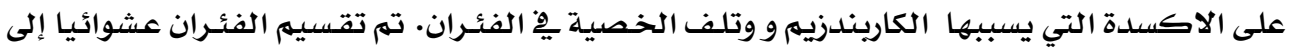

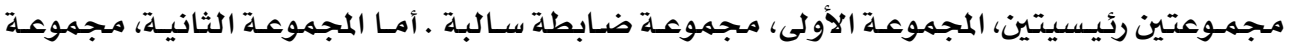

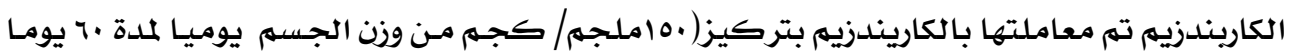

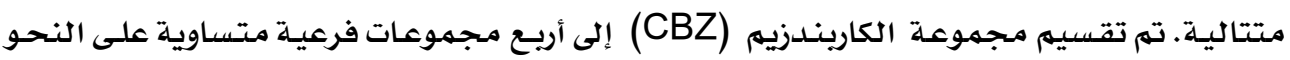

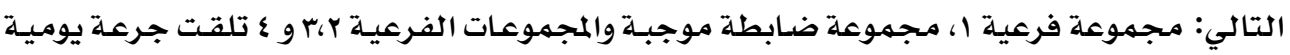

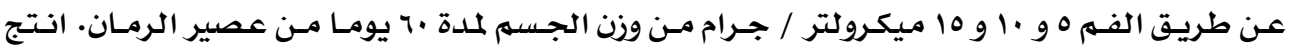

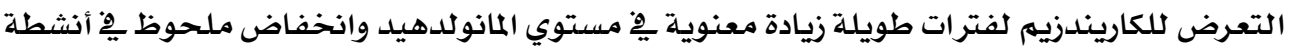

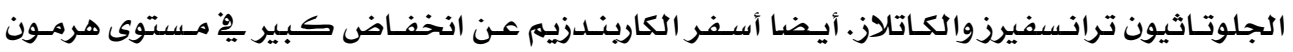

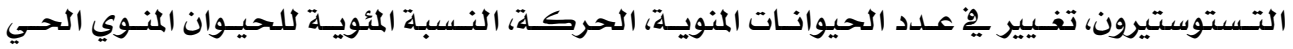

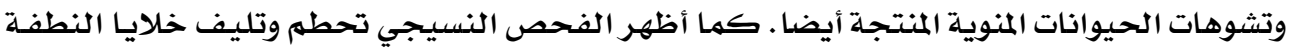

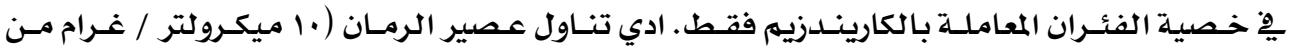

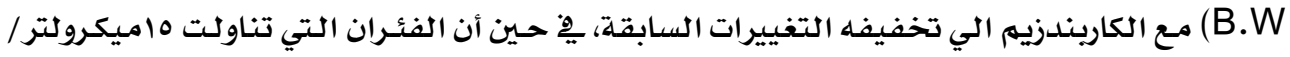

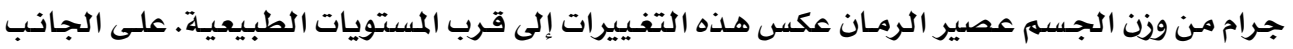

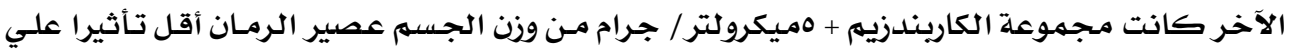

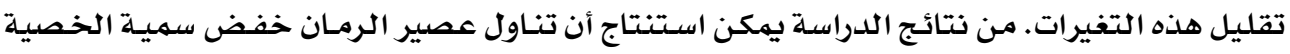

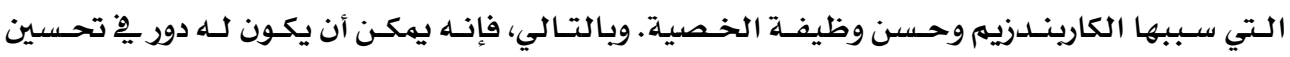
خصوبة ذكور الفئران . الكلمات المفتاحية: رمان، كاريندزيه، الاكسدة وتشوهات الحيوانات المنوية 